\title{
Pemanfaatan Pelepah Pisang Menjadi Produk Inovatif sebagai Upaya Peningkatan Pendapatan Ekonomi Keluarga di Desa Jamberejo Kecamatan Kedungadem Kabupaten Bojonegoro
}

\author{
Nur Laila Rahmawati, Indah Fajrotuz Zahro, Asnawi, Nurul Fitriandari' Eryul \\ Mufidah \\ Sekolah Tinggi Agama Islam (STAI) Attanwir Bojonegoro \\ lailaabdullah899@gmail.com, indahfajrotuzzahro@gmail.com, asnawibjn@gmail.com, \\ nfitriandari@gmail.com, eryulmufi@gmail.com
}

\begin{tabular}{ll|l|l|l|l} 
Received : Nov 3th 2018 & Revised : Feb 08 2019 & Accepted $\quad$ April 6 $6^{\text {th }} 2019$ \\
\hline
\end{tabular}

\begin{abstract}
The economic challenge in the era of ASE AN Economic Community (MEA) is economic competition in the ASEAN countries. Consequently, efforts to improve Small and Medium Enterprises (SMEs) must be sustainable and should be done by synergizing among the social community, higher education, and the business community. To implement it, Jamberejo village of Kedungadem Sub-district, Bojonegoro developed assets that the social community has, that is banana bark which was able to be used as crafts that have economic value. By using Participatory Action Research (PAR) method, 57 women and higher education were invited to make crafts from banana bark to be used as a bome industry business. Based on 6 samples of product, the business got a profit of Rp. 2,100,000. Return of Investment (ROI) is about 2.2 months. Then the average income level of the Jamberejo people has increased by $42.9 \%$ or equivalent to $\mathrm{R}$. 900,000 per month. It happened after they got a mentoring program for the innovation of banana bark.
\end{abstract}

Keywords: Utilization of Banana Bark, Innovative Products, Increasing Economic Income

\section{Pendahuluan}

Perwujudan dimensi pembangunan yang berbasis pemerataan dan kewilayahan disertai membangun Indonesia dari pinggiran dengan memperkuat daerah-daerah dan desa dalam kerangka Negara Kesatuan merupakan amanat Nawacita. Peningkatan daya saing Usaha Kecil Menengah (UKM), terlebih UKM yang ada di pedesaan tidak hanya kewajiban pemerintah saja, namun elemen lain seperti perguruan tinggi juga mempunyai peran yang signifikan dalam pengembangan UKM di pedesaan. UKM di pedesaan perlu diperkuat daya saingnya mengingat tertinggalnya UKM pedesaan dari teknologi dan manajemen professional. ${ }^{1}$

Tahun 2016 adalah tahun pertama diberlakukannya perdagangan kawasan Asia yang disebut dengan ASEAN Economy Community (AEC) atau masyarakat Ekonomi ASEAN (MEA). ${ }^{2}$

\footnotetext{
${ }^{1}$ Agus Sukoco et al., "The Development of the Central Business District (CBD) Based on Public-Private Partnership," IJTI (International Journal Of Transportation And Infrastructure) 1, no. 1 (2017): 9-14.

2 Myrna S. Austria, "Moving Towards an ASEAN Economic Community," East Asia 29, no. 2 (June 1, 2012): 141-156; Lihat juga dalam Michael S. H. Heng, “Advancing Community Building for ASEAN," East Asia 32, no. 4 (December 1, 2015): 421-440.
}

Volume 3, Number 1, Mei 2019|21

Pemberdayaan Ekonomi Transformatif: Pendampingan Kewirausahaan Inovasi Pelepah Pisang Pada Masyarakat Jamberejo Kedungadem Bojonegoro

Nur Laila Rahmawati, Indah Fajrotuz Zahro, Asnawi, Nurul Fitriandari, Eryul Mufidah 
MEA menyepakati terbentuknya pasar tunggal ASEAN dan basis produksi yang terintegrasi sehingga akan terjadi arus barang dan jasa, investasi, modal, serta tenaga kerja ahli secara bebas. ${ }^{3}$ Salah satu peran penting yang bisa dimainkan akademisi perguruan tinggi dalam melaksanakan Tridharma Perguruan Tinggi melalui pengabdian masyarakat adalah dalam bentuk riset, pendampingan kewirausahaan, dan klinik bisnis. Terlebih perguruan tinggi Islam, maka peran penting yang harus diemban akademisi adalah mengintegrasikan misi-misi keIslaman dalam segenap pengabdiannya.

Sehubungan hal tersebut, tantangan bagi usaha kecil menengah (UKM) adalah upaya untuk terus meningkatkan daya saing melalui peningkatan produktivitas dan kualitas produk. Hal ini sesuai dengan harapan Kementerian Koperasi dan Usaha Kecil Menengah (Kemenkop UKM) yang mendorong usaha kecil meningkatkan kualitas dengan menyesuaikan produknya sesuai Standar Nasional Indonesia (SNI). Keinginan berwirausaha biasanya muncul karena kegemaran terhadap jenis usaha, keinginan untuk mandiri, tuntutan kebutuhan serta impian personal. Secara sederhana arti wirausahawan adalah orang yang berjiwa berani mengambil resiko untuk membuka usaha dalam berbagai kesempatan. Sedangkan kewirausahaan merupakan suatu kemampuan dalam hal menciptakan kegiatan usaha. ${ }^{5}$ Bermunculannya banyak usaha baru membuat persaingan semakin ketat. Perubahan-perubahan yang terjadi dalam persaingan usaha menciptakan perubahan kebutuhan pelanggan, pengelolaan produk serta pangsa pasar. ${ }^{6}$ Selain itu, inovasi produk sangat penting. Produk yang dipasarkan oleh pemilik usaha harus memiliki inovasi kekinian dan bisa diterima masyarakat luas. Oleh karena itu, pendampingan usaha kecil dipedesaan termasuk dalam hal ini pendampingan kewirausahaan inovasi pelepah Pisang pada masyarakat Jamberejo oleh akademisi perguruan tinggi Islam menemukan relevansinya.

Desa Jamberejo Kecamatan Kedungadem Kabupaten Bojonegoro merupakan bagian integral dari sistem perwilayahan Kecamatan Kedungadem. Batas-batas desa ini sebelah utara Desa Mlinjeng Kecamatan Sumberrejo, sebelah selatan Desa Sidomulyo Kecamatan Kedungadem, sebelah Timur Desa Mojorejo Kecamatan Kedungadem, sedangkan sebelah barat Desa Tlogohaji

\footnotetext{
${ }^{3}$ Muh Barid Nizaruddin Wajdi, Yuli Choirul Ummah, and Devit Etika Sari, "UKM Development Business Loan," IJEBD (International Journal Of Entrepreneurship And Business Development) 1, no. 1 (2017): 99-109.

${ }^{4}$ News Online, Peran UMKM Hadapi MEA, n.d., accessed September 17, 2019, www.jatengprov.go.id/.

${ }^{5}$ Kasmir, Kewirausabaan (Jakarta: Raja Grafindo Persada, 2006), 19.

${ }^{6}$ Pembukaan usaha baru yang sangat pesat saat ini menyebabkan persaingan yang makin kompetitif dalam dunia usaha. Banyak dunia usaha melakukan berbagai cara dan strategi agar usaha barunya dapat berkembang dan mendapat pelanggan, salah satu strategi yang digunakan saat ini ialah menggunakan IT sebagai "alat" untuk memenangkan persaingan tersebut. Lihat dalam Constantinos Giannoulis, Michaël Petit, and Jelena Zdravkovic, "Modeling Competition-Driven Business Strategy for Business IT Alignment," in Advanced Information Systems Engineering Workshops, ed. Camille Salinesi and Oscar Pastor, Lecture Notes in Business Information Processing (Springer Berlin Heidelberg, 2011), 16-28; Ada juga IT digunakan sebagai strategi untuk mengolah bahan yang tidak terpakai dan dikelola menjadi sebuah komoditi untuk memberdayakan perekonomian masyaralat. Lihat dalam Amang Fathurrohman et al., "Implementasi Manajemen Bank Sampah IT pada Komunitas Bank Sampah berbasis Masyarakat, Pemuda, dan Sekolah di Kabupaten Pasuruan," Jurnal Pengabdian Kepada Masyarakat (n.d.): 15.
} 
Kecamatan Sumberjo. Dan secara geografis Desa Jamberejo ini merupakan dataran tinggi. Suhu rata-rata perharinya 34 sampai dengan $36^{\circ} \mathrm{C}$. Luas wilayah Desa Jamberejo kurang lebih sekitar 552.4909 hektar, untuk luas Kas Desa sekitar 113.11 hektar, untuk luas tanah Bengkok 56.21 hektar, untuk luas area persawahan mencapai sekitar 383.00 hektar, untuk luas perumahan 41.870 hektar, untuk luas pendidikan 7.403 hektar dan luas tanah lainnya 49.1021 hektar utuk pemakaman, pemukiman, pekaraangan dan lain-lain. ${ }^{7}$

Tingkat pendapatan rata-rata penduduk Desa Jamberejo perhari yaitu Rp. 40.000,00 dengan mata pencaharian warga masyarakat Desa Jamberejo secara umum dapat diklasifikasikan ke dalam beberapa bidang yaitu pertanian, jasa/perdagangan, industri dan lain-lain. Berdasarkan data yang ada, masyarakat yang bekerja di bidang pertanian berjumlah 2.933 jiwa, yang bekerja di bidang perdagangan, berjumlah 130 jiwa, yang bekerja di bidang industri 13 jiwa, yang bekerja di bidang peternakan 485 jiwa dan bekerja di bidang lain-lain ribuan jiwa. Dengan demikian jumlah penduduk yang mempunyai mata pencaharian berjumlah 3.561 dari 3912 jiwa. ${ }^{8}$ Berikut ini adalah tabel jumlah penduduk beserta presentasenya berdasarkan mata pencaharian.

Tabel 1.

Jumlah dan Persentase Mata Pencaharian Masyarakat Desa Jamberejo ${ }^{9}$

\begin{tabular}{|c|l|c|c|}
\hline No & Mata Pencaharian & Jumlah & Presentase \\
\hline 1 & Bidang Pertanian & 2.933 jiwa & $74,97 \%$ \\
\hline 2 & Bidang Perdagangan & 130 jiwa & $3,32 \%$ \\
\hline 3 & Bidang Industri & 13 jiwa & $0,33 \%$ \\
\hline 4 & Bidang Peternakan & 485 jiwa & $12,39 \%$ \\
\hline 5 & Bidang Lain & 351 jiwa & $8,97 \%$ \\
\hline \multicolumn{2}{|c|}{ Jumlah } & $\mathbf{3 9 1 2}$ jiwa & $\mathbf{1 0 0} \%$ \\
\hline
\end{tabular}

Berdasarkan tabel di atas, mayoritas masyarakat desa Jamberejo bermata pencaharian di bidang pertanian, baik sebagai petani maupun buruh tani. Dengan kata lain, mayoritas dari masyarakat desa Jamberejo menggantungkan perekonomian pada hasil pertanian, namun untuk saat ini perekonomian mereka sedikit mengalami penurunan dikarenakan gagal panen yang disebabkan oleh hama dan kekeringan. Selain itu, masyarakat desa juga tidak mempunyai keterampilan lain selain bertani, sehingga saat ini banyak masyarakat yang terpaksa tidak bekerja (menjadi pengangguran), karena masyarakat terbiasa hanya menggantungkan ekonominya dari hasil 4 .

${ }^{7}$ Pemerintahan Desa Jamberejo, “Profil Desa Jamberejo Kecamatan Kedungadem Kabupaten Bojonegoro Tahun 2018,” 2018,

8 Ibid., 7.

${ }^{9}$ Ibid., 8 .

Volume 3, Number 1, Mei 2019| 23

Pemberdayaan Ekonomi Transformatif: Pendampingan Kewirausahaan Inovasi Pelepah Pisang Pada Masyarakat Jamberejo Kedungadem Bojonegoro

Nur Laila Rahmawati, Indah Fajrotuz Zahro, Asnawi, Nurul Fitriandari, Eryul Mufidah 
panen. Sedangkan di bidang lain, terdapat masyarakat bekerja sebagai PNS, perangkat desa, dan sebagainya.

Fenomena unik yang berkembang di desa Jamberejo yakni banyak sekali ditemukan tanaman pohon pisang yang tumbuh hampir di setiap area pekarangan rumah warga. Keadaan ini dapat dijadikan suatu potensi usaha dengan mengembangkan value added dari kebermanfaatan tanaman pisang tersebut, sebagaimana pemanfaatan bonggol pisang di Bali dimana secara tradisional bonggol pisang telah diolah menjadi makanan bernama 'tum' atau pepes. ${ }^{10}$ Seperti halnya bagian pelepah pisang yang notabene pemanfaatannya belum seterkenal kegunaan buah maupun daun pisang di benak masyarakat awam. Padahal pelepah pisang dapat dimanfaatkan untuk menciptakan suatu produk berupa hasil kerajian yang memiliki nilai estetika tinggi. ${ }^{11}$ Produk dikatakan memiliki nilai estetika jika terdapat daya tarik produk terhadap panca indera. ${ }^{12}$ Sedangkan estetika merupakan salah satu dimensi pengukur kualitas suatu produk yang layak diterima oleh pasar, meliputi keindahan desain produk, keunikan model produk, dan kombinasi warna. Dengan kata lain, pengolahan produk kerajinan berbahan dasar pelepah pisang dapat diajukan sebagai suatu tindakan solutif dalam mengatasi masalah perekonomian warga. Terlebih lagi, mengingat kemudahan warga untuk mengakses tanaman pohon pisang yang dapat ditemui di samping maupun di belakang setiap rumah warga.

Pada dasarnya, pendampingan kewirausahaan melalui inovasi pelepah pisang dalam jangka panjang merupakan bentuk pemberdayaan ekonomi masyarakat desa Jamberejo secara komprehensif. Pemberdayaan dalam bahasa Arab disebut dengan kata 'tamkin', yakni menunjukkan atas kemampuan melakukan suatu kekokohan, memiliki kekuatan, kekuasaan, pengaruh, dan memiliki kedudukan atau tempat, baik itu bersifat hissi (dapat dirasakan/materi) seperti menetapnya burung dalam sangkarnya atau bisa bersifat ma'nawi seperti kokohnya atau teguhnya orang tersebut di sisi penguasa. ${ }^{13}$ Pemberdayaan diartikan sebagai upaya untuk memberikan daya (empowerment) atau penguatan (strengthening) kepada masyarakat. ${ }^{14}$

Pemberdayaan mengandung arti perbaikan mutu hidup atau kesejahteraan setiap individu dan masyarakat, antara lain dalam arti perbaikan ekonomi terutama kecukupan pangan, perbaikan kesejahteraan sosial (pendidikan dan kesehatan), kemerdekaan dari segala bentuk penindasan,

${ }^{10}$ Badan Layanan Pengadaan (BPS, 2013).

11 Dari hasil-hasil penelitian, sangat banyak sekali manfaat pelepah pisang. Lihat dalam Nur Lailatul Fadhilah and Triastuti Rahayu, "Potensi Pelepah Daun Pisang Kepok Sebagai Hand Sanitizer Alami” (PhD Thesis, Universitas Muhammadiyah Surakarta, 2017); Sri Murtini, "Pembuatan Pulp Dari Pelepah Pisang Dengan Proses Soda" (PhD Thesis, Undip, 2010); Norbertus Kaleka and Edi Tri Hartono, "Kerajinan Pelepah Pisang," Solo: Arcita (2013).

${ }^{12}$ Fandy Tjiptono, Strategi Pemasaran (Yogyakarta: Andi, 2002), 25.

${ }^{13}$ Yulizar D. Sanrego and Moch Taufik, Fiqih Tamkin (Fiqih Pemberdayaan) (Jakarta: Qisthi Press., 2016), 75.

14 Totok Mardikanto and Poerwoko Soebiato, Pemberdayaan Masyarakat Dalam Perspektif Kebijakan Publike (Bandung: Alfabeta, 2015), 23. 
terjaminnya keamanan, serta terjaminnya hak asasi manusia yang bebas dari rasa takut dan kekhawatiran. ${ }^{15}$ Oleh karena itu, pemberdayaan menjadi salah satu program yang digalakkan pemerintah untuk mengentaskan kemiskinan, khususnya dalam membangun ekonomi masyarakat pedesaan. Dengan demikian, kegiatan pendampingan kewirasausahaan melalui inovasi pelepah pisang dilaksanakan bertujuan untuk membantu menyelesaikan permasalahan ekonomi pada masyarakat desa Jamberejo Kecamatan Kedungadem Kabupaten Bojonegoro.

\section{Metode}

Strategi yang dilakukan untuk mencapai kondisi yang diharapkan untuk pendampingan kewirausahaan inovasi pelepah Pisang adalah PAR (Participatory Action Research). PAR adalah suatu cara membangun jembatan untuk menghubungkan orang. Jenis penelitian ini adalah suatu proses pencarian pengembangan pengetahuan praktis dalam memahami kondisi sosial, politik, lingkungan, atau ekonomi. Penelitian ini mencari sesuatu untuk menghubungkan proses penelitian ke dalam proses perubahan sosial. ${ }^{16}$ Dengan kata lain, PAR merupakan proses penelitian dalam lingkaran kepentingan orang dan menemukan solusi praktis bagi masalah bersama dan isu-isu yang memerlukan aksi dan refleksi bersama, dan memberikan kontribusi bagi teori praktis. Berikut adalah analisa pohon masalah terkait problematika yang ada di Desa Jamberejo.

Proses forum FGD (Focus Group Discusion) yang telah dilakukan bersama dengan masyarakat desa Jamberejo mengungkapkan berbagai permasalahan yang mereka rasakan di desa Jamberejo di berbagai bidang seperti perekonomian, pendidikan, keagamaan dan manfaat limbah atau sampah dari pelepah pisang. Dalam musyawarah tersebut, mereka lebih condong mengungkapkan seputar tentang limbah atau sampah pelepah pisang. Jika diamati masalah yang dihadapi oleh masyarakat desa Jamberejo dikarenakan kurang adanya pemanfaatan limbah atau sampah, maka yang lebih kita titik fokuskan yaitu memanfaatkan pelepah pisang sebagai kerajinan yang mampu menambah perekonomian warga. Pohon pisang yang tidak dimanfaatkan mengakibatkan bertambahnya sampah pelepah pisang di desa Jamberejo, dan secara tidak langsung jika permasalahan sampah ini tidak segera diatasi dapat menimbulkan dampak bagi berkembangnya wabah penyakit.

Inti dari masalah di Desa Jamberejo adalah minimnya pemanfaatan inovasi dari pelepah pisang dalam meningkatkan perkonomian warga. Hal ini dikarenakan masyarakat desa Jamberejo terlalu bergantung dengan hasil pertanian yang dalam beberapa waktu terakhir memiliki hasil

\footnotetext{
${ }^{15}$ Ibid., 28.

${ }^{16}$ Sara Kindon, Rachel Pain, and Mike Kesby, Participatory Action Research Approaches and Methods: Connecting People, Participation and Place (Routledge, 2007), 504.
} 
kurang maksimal karena banyak petani Desa Jamberejo yang gagal panen. Kondisi ini menyebabkan penghasilan rendah, kesejahteraan masyarakat berkurang, dan masyarakat menjadi pengangguran musiman. Selanjutnya kurangnya pemanfaatan inovasi pelepah pisang karena kurang adanya modal dan kurangnya skill (keahlian) yang baik dalam pengolahan pelepah pisang.

Perekonomian berpengaruh besar bagi masyarakat desa Jamberejo, perekonomian tani sangat berpengaruh bagi masyarakat desa Jamberejo, wirausaha juga berepengaruh untuk meningkatakan perekonomian masayarakat desa Jamberejo, kerajinan seharusnya juga berpengaruh bagi mereka, namun kondisi saat ini tidak ada yang di optimalkan, juga komunitas kerajinan perlu dioptimalkan oleh pemerintah desa untuk di ajak bekerja sama agar hasil dari kerajinan pelepah pisang di desa Jamberejo ketika pendistribusiannya lebih mudah, sehingga kemajuan perekonomian desa Jamberejo lebih optimal.

\section{Hasil dan Diskusi}

Berdasarkan wawancara dengan Kepala Desa Jamberejo diperoleh informasi bahwa desa ini memiliki potensi untuk mengembangkan limbah atau sampah dari pelepah pisang, yang mana di desa Jamberejo terdapat banyak pohon pisang yang nantinya pelepah pisang dari pohon pisang dapat dimanfaatkan oleh masyakat desa Jamberejo. Selain itu, banyak sekali tanah kosong di samping atau di belakang rumah yang sangat banyak pohon pisangnya, sebangaimana diketahui bahwa pohon pisang yang sudah berbuah dan diambil buah pisangnya maka akan menjadi limbah atau sampah ketika pelepah pisang tersebut tidak dimanfaatkan. ${ }^{17}$

Dengan begitu, pohon pisang yang dimanfaatkan pelepah pisangnya berpotensi meningkatkan perekonomian keluarga atau masyarakat desa Jamberejo. Sedangkan sampai saat ini pelepah pisang di desa Jamberejo masih kurang adanya pemanfaatan pelepah pisang. Adapun berbagai program yang direncanakan untuk masyarakat Desa Jamberejo antara lain kegiatan yang berupaya untuk membangkitkan motivasi masyarakat desa jamberejo melalui pelatihan kerajinan pelepah pisang.

Program kegiatan yang dilakukan yaitu memberikan motivasi kepada masyarakat desa Jamberejo untuk menjaga kebersihan lingkungan, berinovasi dan meningkatkan pendapatan keluarga dengan memanfaatkan pelepah pisang melalui kegiatan pelatihan kerajinan pelepah pisang. Guna membangkitkan ibu-ibu dan pemuda-pemudi desa Jamberejo, dengan hal tersebut masyarakat menjadi tidak hanya mengandalkan pertanian untuk memenuhi kebutuhan, tetapi juga dengan memanfaatkan limbah atau sampah pelepah pisang sebagai cara peningkatan

\footnotetext{
17 Wawancara dengan Kepala Desa Jamberejo, hari Rabu tanggal 1 Agustus 2018 di Balai Desa Jamberejo
} 


\section{ENGAGEMENT}

JurnalPengabdian KepadaMasyarakat

ISSN : 2579-8375 (Print)

ISSN : 2579-8391 (Online)

perekonomian masyarakat desa Jamberejo, sehingga ketika hasil pertanian kurang maksimal masyarakat desa Jamberejo masih bisa memenuhi kebutuhannya. Pemberian motivasi ini dipandu oleh Ibu Nur Laila Rahmawati, MPd.I dan Ibu Indah Fajrotuz Zahro, M.Psi di Balai Desa Jamberejo pada hari Rabu tanggal 1 Agustus 2019 dari pukul 09.00- 13.00 Wib. Jumlah peserta pada kegiatan motivasi ini adalah 57. Output dari kegiatan motivasi ini adalah masyarakat desa Jamberejo memiliki keinginan untuk meningkatkan perekonomian keluarga dengan memanfaatkan pelepah pisang. Dengan adanya pelatihan yang kami adakan di desa Jamberejo tentang kerajinan pelepah pisang diharapkan mampu meningkatkan perekonomian masyarakat melalui inovasiinovasi dari kerajinan pelepah pisang.

Di desa Jamberejo memiliki potensi untuk mengembangkan pelepah pisang, sedangkan masih banyak pelepah pisang yang tidak dimanfaatkan atau terbuang sia-sia sehingga perlu adanya kesadaran masyarakat tentang memanfaatkan pelepah pisang tersebut. Oleh karena itu, kami selaku tim mensosialisasikan bahwa pelepah pisang merupakan bahan yang jika diolah akan dapat meningkatkan perekonomian dan mengurangi sampah serta mengurangi pengangguran di desa Jamberejo, selain itu ibu- ibu dan pemuda pemudi desa Jamberejo selalu bisa berkreatifitas dalam hal membuat kerajinan. Kegiatan pelatihan dari pelepah pisang ini dipandu oleh Bapak Asnawi, MPd.I Lokasi pelatihan ini di rumah warga Bapak Sugiyatno. Masyarakat desa Jamberejo mengikuti kegiatan pelatihan ini dengan membuat beberapa kerajinan berupa topi, tempat tisu dengan bahan dasar dari pelepah pisang.
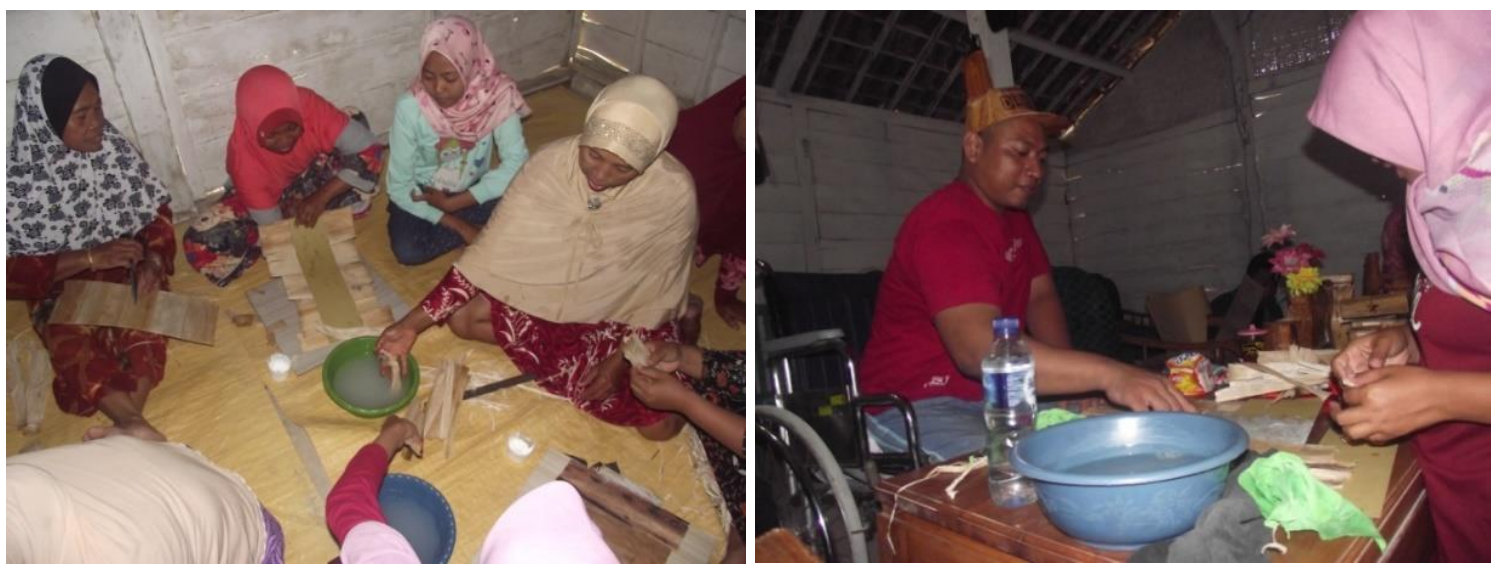

Gambar 1. Pelatihan kerajinan pelepah pisang (kiri) dan Narasumber membantu pengembangan inovasi pelepah pisang (Kanan)

Bisnis merupakan kegiatan yang dapat banyak memberikan keuntungan bagi masyarakat ketika mampu memanegemen bisnis dengan baik, sehingga perlu disadari bahwa pentingnya dalam memenejemen bisnis atau usaha. Dalam hal ini perlu juga adanya kekompakan untuk 
memanfaatkan limbah pelepah pisang oleh masyarakat, sehingga masyarakat tidak hanya bergantung dengan hasil pertanian, sedangkan hasil pertanian dari beberapa tahun kemarin tidak memenuhi kebutuhan dari masyarakat Jamberejo. Selain itu dalam memenejemen bisnis perlu adanya pula perencanaan, pengelolaan, dan pengoprasian sebuah usaha atau bisnis sehingga mampu mencakup semua pengaturan baik dari dalam proses pengerjaan suatu bisnis untuk mencapai suatu tujuan yang masyarakat inginkan. Dari permulaan usaha yang akan mulai dibangun perlu menggunakan yang namanya menejemen bisnis agar laju usaha mempunyai target dan dapat memenuhi kebutuhan dan meningkatkan perekonomian.

Kegiatan pelatihan dengan materi Manajemen Bisnis dipandu oleh Ibu Eryul Mufidah, MM. Output dari kegiatan ini adalah masyarakat memiliki pengetahuan tentang cara memanajemen bisnis bagi pemula. Pemasalahan yang mendasar yang sering dihadapi oleh masyarakat Jamberejo adalah kurang adanya pemanfaatan sampah atau limbah, sehingga perlu adanya kreativitas untuk menjadikan limbah tersebut sebagai suatu produk yang bernilai ekonomis. Jadi, ketika limbah atau sampah tersebut menjadi produk atau kerajinan maka perlu adanya distibusi atau pemasaran. Setiap produk yang mempunyai nilai ekonomis tentunya memiliki strategi pemasaran tersendiri yang harus dijalankan dalam melaksanakan kegiatan bisnisnya, untuk memudahkan dalam mendisribusikan produk perlu juga yang namanya komunitas agar dalam pendistribusian produk lebih mudah.

Kegiatan Distribusi Bisnis ini dipandu oleh Ibu Nurul Fitriandari, MM. Dalam hal ini, masyarakat diajarkan cara pengemasan produk dan dilatih untuk memahami cara menawarkan produk dengan baik. Pada kegiatan distribusi bisnis ini, masyarakat mempraktekkan cara untuk mengemas produk dan menawarkannya baik secara manual maupun melalui media sosial. Untuk pendistribusian melalui media sosial lebih disenangi oleh peserta pelatihan yang berusia muda karena sebagian besar peserta remaja dan dewasa awal memiliki gadget dan memiliki akun media sosial. Beragam strategi di atas mendorong pemuda pemudi Jamberejo tergugugah dalam memanfaatkan pelepah daun pisang yang belum dimanfaatkan menjadi produk bernilai ekonomis.

Implikasi dari program kerajinan pelepah pisang menjadi produk bernilai ekonomis ini mampu memberikan semangat warga dalam pentingnya pemanfaatan pelepah pisang. Selain itu kegiatan ini juga mampu mengurangi limbah atau sampah dari pohon pisang serta peningkatan kepedulian masyarakat Desa Jamberejo terhadap lingkungan sekitar. Selain itu, melalui inovasi pelepah pisang ini, masyarakat memiliki keahlian dalam kerajinan pelepah pisang, sehingga mereka mendapatkan nilai tambah pendapatan ekonomi keluarga selain mendapatkan pendapatan dari hasil pertanian. 


\section{ENGAGEMENT}

GurnalPengabdianKepadaMasyarakat

ISSN : 2579-8375 (Print)

ISSN : 2579-8391 (Online)
This work is licensed under a Creative Commons Attribution-ShareAlike 4.0 International License. CC BY SA

Nilai tambah pendapatan selama kegiatan pendampingan kewirausahaan inovasi pelepah Pisang dalam 2 bulan bagi masyarakat Desa Jamberejo mampu mendapatkan pendapatan bersih Rp 2.100.000,-. Kenyataan tersebut lebih besar jika dibandingkan pendapatan rata-rata pendapatan masyarakat Jamberejo melalui pertanian yaitu Rp 1.200.000,-. Data selengkapnya sebagaimana tersaji dalam tabel berikut ini:

Tabel 2. Analisa Ekonomi

\begin{tabular}{|c|c|c|c|}
\hline \multicolumn{4}{|l|}{ Modal Awal } \\
\hline Nama Perlengkapan & Modal & Jumlah & \\
\hline Pelepah Pisang & @Rp.1500 x 1000 Lembar & Rp.1.500.000,- & \\
\hline Lem Perekat dan Hiasan & @Rp.2500 x 1000 Lembar & Rp.2.500.000,- & \\
\hline Kertas Karton & Rp. $500.000,-$ & Rp. 500.000,- & \\
\hline ATK & Rp. 150.000,- & Rp. 150.000,- & \\
\hline \multicolumn{3}{|l|}{ Total Modal Awal } & Rp.4.650.000,- \\
\hline \multicolumn{4}{|l|}{ Biaya Operasional } \\
\hline \multicolumn{2}{|l|}{ Bahan Baku Perbulan } & Rp.6.000.000,- & \\
\hline \multicolumn{2}{|l|}{ Gaji Pegawai } & Rp. 750.000,- & \\
\hline \multicolumn{2}{|l|}{ Biaya Listrik } & Rp. 300.000,- & \\
\hline \multicolumn{2}{|l|}{ Biaya Transportasi } & Rp. 200.000,- & \\
\hline \multicolumn{2}{|l|}{ Biaya Promosi } & Rp.2.000.000,- & \\
\hline \multicolumn{2}{|l|}{ Kemasan Plastik } & Rp. 600.000,- & \\
\hline \multicolumn{3}{|l|}{ Total Biaya Operasional } & Rp. 10.150.000,-- \\
\hline \multicolumn{4}{|l|}{ Omset Bulanan } \\
\hline Kap Lampu & @Rp.50.000x 50 & Rp.2.500.000,- & \\
\hline Tas & @Rp.40.000x 100 & Rp.2.500.000,- & \\
\hline Sandal & @.Rp.20.000x 100 & Rp.2.000.000,- & \\
\hline Tempat Pensil & @Rp.15.000x 75 & Rp.1.124.000,- & \\
\hline Boneka & @.Rp.25.000x 75 & Rp.1.875.000,- & \\
\hline Pigura & (a)p.15.000x 50 & Rp. $\quad 750.000,-$ & \\
\hline \multicolumn{3}{|l|}{ Total Omset Bulanan } & Rp. 12.250.000,- \\
\hline \multicolumn{3}{|l|}{ Laba Bersih } & Rp. $2.100 .000,-$ \\
\hline
\end{tabular}

Dari data penjualan selama 1 bulan selama adanya pendampingan inovasi pelepah Pisang pada masyarakat Jamberejo pada sampel 6 produk menghasilkan laba bersih sebesar Rp 2.100.000. ROI (Return of Invesment) yaitu kurang lebih 2,2 bulan. Dari pernyataan di atas dapat disimpulkan bahwa pendapatan masyarakat Jamberejo khususnya komunitas wirausaha inovasi pelepah Pisang mengalami peningkatan sebesar Rp 900.000 setiap bulan. Dengan kata lain, terjadi peningkatan pendapatan masyarakat sebesar $42,9 \%$ setelah adanya program pendampingan inovasi pelepah pisang pada masyarakat Jamberejo, Kecamatan Kedungadem, Kabupaten Bojonegoro.

\section{Kesimpulan}


Dari beberapa pemaparan yanng diatas ada yang menjadi problem utama masyarakat Jamberejo adalah tingkat pendapatan perekonomian yang masih rendah karena masyarakat Desa Jamberejo masih memiliki ketergantungan terhadap sektor pertanian penanaman padi. Selain itu, banyaknya pelepah pisang yang melimpah belum dimanfaatkan menjadi produk bernilai ekonomis bagi masyarakat Jamberejo karena belum memiliki keahlian yang cukup dalam pengolahan pelepah pisang.

Dari permasalahan tersebut maka adanya pendampingan kewirauahaan untuk inovasi pelepah pisang melalui kerajinan pelepah pisang yang dilakukan di desa Jamberejo mampu memberikan motivasi dan membangkitkan minat dalam mengembangkan produk pengolahan limbah pelepah pisang menjadi produk bernilai ekonomis. Pendampingan kewirausahaan inovasi pelepah Pisang ini juga mampu memberikan perubahan dalam penambahan pendapatan sampai $42,9 \%$ dan penataan menajemen keuangan proses produksi dan administrasi menjadi lebih tertib dan terkontrol dengan baik, dibanding sebelumnya yang masih tercampur antara kebutuhan proses produksi dan keperluan kebutuhan rumah tangga. Selain itu, para pelaku usaha juga memiliki kemampuan inovasi dan distribusi hasil produk pelepah pisang yang dihasilkannya.

Untuk itu perlu diajukan rekomendasi sebagai berikut: Pertama, masyarakat dan pihak UKM Dengan adanya pemecahan solusi dari permasalahan yang dihadapi di desa Jamberejo, penduduk perlu benar-benar mengaplikasikan metode atau cara pembuatan kerajinan pelepah pisang untuk meningkatkan perekonomian mereka. Sehingga perlu tindak lanjut dalam pengembangan beragam produk pembuatan kerajinan pelepah pisang. Kedua, Bagi pemerintah agar adanya perhatian khusus mengenai pemanfaatan pelepah pisang, perlu adanya pembentukan kelompok pengrajin untuk memberikan keterkaitan dan solidaritas antar pengarajin supaya nantinya mampu memberikan akses pemasaran hasil kreatifitas dari kerajinan pelepah yang lebih optimal. Ketiga, permodalan juga menjadi kendala pada masyarakat, oleh kerena itu pembuatan anggaran untuk pemberian pinjaman kepada masyarakat guna memberi sokongan modal untuk pengrajin merupakan solusi untuk membangkitkan kembali minat masyarakat dalam memanfaatkan pelepah pisang.

\section{Daftar Referensi}

Austria, Myrna S. "Moving Towards an ASEAN Economic Community." East Asia 29, no. 2 (June 1, 2012): 141-156. 
Fadhilah, Nur Lailatul, and Triastuti Rahayu. "Potensi Pelepah Daun Pisang Kepok Sebagai Hand Sanitizer Alami.” PhD Thesis, Universitas Muhammadiyah Surakarta, 2017.

Fathurrohman, Amang, M Dayat, Zainul Ahwan, M Daimul Abror, Lukman Hakim, Syukur Sugeng Apriwiyanto, Imam Syafi'i, Fafit Rahmat Aji, and Mulyono Wobisono. "Implementasi Manajemen Bank Sampah IT pada Komunitas Bank Sampah berbasis Masyarakat, Pemuda, dan Sekolah di Kabupaten Pasuruan." Jurnal Pengabdian Kepada Masyarakat (n.d.): 15.

Giannoulis, Constantinos, Michaël Petit, and Jelena Zdravkovic. "Modeling Competition-Driven Business Strategy for Business IT Alignment." In Advanced Information Systems Engineering Workshops, edited by Camille Salinesi and Oscar Pastor, 16-28. Lecture Notes in Business Information Processing. Springer Berlin Heidelberg, 2011.

Heng, Michael S. H. "Advancing Community Building for ASEAN." East Asia 32, no. 4 (December 1, 2015): 421-440.

Kaleka, Norbertus, and Edi Tri Hartono. "Kerajinan Pelepah Pisang." Solo: Arcita (2013).

Kasmir. Kewirausahaan. Jakarta: Raja Grafindo Persada, 2006.

Kindon, Sara, Rachel Pain, and Mike Kesby. Participatory Action Research Approaches and Methods: Connecting People, Participation and Place. Routledge, 2007.

Mardikanto, Totok, and Poerwoko Soebiato. Pemberdayaan Masyarakat Dalam Perspektif Kebijakan Publik. Bandung: Alfabeta, 2015.

Murtini, Sri. "Pembuatan Pulp Dari Pelepah Pisang Dengan Proses Soda." PhD Thesis, Undip, 2010.

News Online. Peran UMKM Hadapi MEA, n.d. Accessed September 17, 2019. www.jatengprov.go.id/.

Pemerintahan Desa Jamberejo. "Profil Desa Jamberejo Kecamatan Kedungadem Kabupaten Bojonegoro Tahun 2018," 2018.

Sanrego, Yulizar D., and Moch Taufik. Fiqib Tamkin (Fiqib Pemberdayaan). Jakarta: Qisthi Press., 2016.

Sukoco, Agus, M. Ikhsan Setiawan, Iswachyu Dhaniarti, and Cholil Hasyim. "The Development of the Central Business District (CBD) Based on Public-Private Partnership." IJTI (International Journal Of Transportation And Infrastructure) 1, no. 1 (2017): 9-14.

Tjiptono, Fandy. Strategi Pemasaran. Yogyakarta: Andi, 2002.

Wajdi, Muh Barid Nizaruddin, Yuli Choirul Ummah, and Devit Etika Sari. "UKM Development Business Loan." IJEBD (International Journal Of Entrepreneurship And Business Development) 1, no. 1 (2017): 99-109. 